\title{
AN OVERLOOKED IDENTITY IN NUMBER THEORY
}

\author{
Stevo Bozinovski \\ Department of Mathematics and Computer Science, South Carolina State University, USA \\ and \\ Faculty of Computer Science and Engineering, Ss. Cyril and Methodius University, \\ Skopje, Republic of Macedonia \\ e-mail: $\underline{\text { SBozinovski@ @ssu.edu }}$
}

It is pointed out toward an overlooked identity in Number Theory. Using the observed identity, a new result in Number Theory is obtained, and a new proof of a previously known result is given. Educational aspects are also discussed, pointing toward possible explanation why the observed identity, which looks trivial once observed, has not been pointed out so far.

Key words: Number Theory; overlooked identity; sum of numbers; alternate sum of squares; Plimpton 322

\section{INTRODUCTION}

Number Theory, along with geometry, is the oldest mathematical discipline. Today it is understood as discovering and studying properties of integers in various forms as they appear in nature and mathematics.

Among oldest topics considered in Number Theory are squares of numbers, as well as sums and differences of squares of numbers in relation to geometric shapes. The oldest known written work, the clay tablet cataloged as Plimpton 322, dated 1800 $\mathrm{BC}$, has been found in Larsa, Mesopotamia. In the interpretation of the work (e.g. [1]) it has been pointed out that sum of squares and difference of squares are connected as Pythagorean triplets

$$
\left(a^{2}-b^{2}\right), 2 a b,\left(a^{2}+b^{2}\right) .
$$

Today the school system provides knowledge on the subject, and some very well known identities and names are:

$a^{2}+b^{2}=c^{2}$

Pythagorean triplets

$a^{2}-b^{2}=(a+b)(a-b) \quad$ Factoring the difference of two squares

$1+2+\ldots+n=n(n+1) / 2$ Sum of the first $n$ natural numbers
$\mathrm{T}_{\mathrm{n}}=\mathrm{n}(\mathrm{n}+1) / 2 \quad$ Triangular numbers

The literature on the subject is voluminous and we will mention recently published book [2] as well as more classical ones [3, 4]. There is a monograph entirely devoted to the sum of squares of integers [5].

This paper points out that although properties of sums and difference of squares have been studied since beginning of Number Theory, there is a simple and useful property that has been overlooked so far.

In the sequel the paper states, as Lemma 1, the main observation, about the difference of squares of pairs of consecutive integers. Then it points out the usefulness of the observed identity, by using it to prove one known and one new result in Number Theory.

\section{An overlooked identity in Number Theory}

Lemma 1. The sum of two consecutive descending integers is equal to the difference of their squares, i.e.

$$
(\forall \mathrm{n} \in \mathrm{Z}):(\mathrm{n}+1)+\mathrm{n}=(\mathrm{n}+1)^{2}-\mathrm{n}^{2}
$$


Proof.

$(\mathrm{n}+1)^{2}-\mathrm{n}^{2}=\mathrm{n}^{2}+2 \mathrm{n}+1-\mathrm{n}^{2}=2 \mathrm{n}+1=$ $(n+1)+n$.

As illustration let us consider a positive (e.g. $n=9$ ), and a negative (e.g. $n=-9$ ) integer.

In the case $n=9$ we have:

$$
10+9=19=10^{2}-9^{2} .
$$

In the case $\mathrm{n}=-9$ we have

$$
-8-9=-17=(-8)^{2}-(-9)^{2} \text {. }
$$

In the case $n=0$ the equation (1) gives $1=1$.

A visual illustration of Lemma 1 can be given for positive integers, and for case $n=4$ it is given in Figure 1. By analogy, an illustration can be given for any $n$.

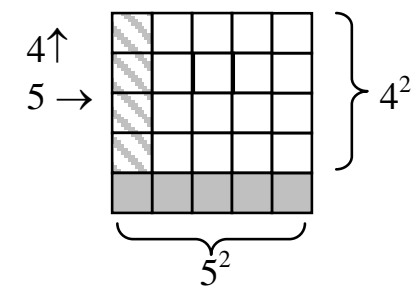

Figure 1. A visual illustration of Lemma 1 for the case $n=4$.

The identity is useful for proving other properties of numbers

This section shows that the observation (1) is useful in proving other properties of numbers, in this case a property of alternate sum of squares of integers.

Corollary 1: The alternate sum of the squares of consecutive descending numbers down to 0 , is equal to the sum of those numbers. Formally:

$$
\sum_{i=0}^{n}(-1)^{i}(n-i)^{2}=\sum_{i=0}^{n}(n-i)=\frac{n(n+1)}{2} .
$$

In expanded form we have

$\mathrm{n}^{2}-(\mathrm{n}-1)^{2}+\ldots+2^{2}-1^{2}+0^{2}=\mathrm{n}+(\mathrm{n}-1)+\ldots+2+1+0$ or

$\mathrm{n}^{2}-(\mathrm{n}-1)^{2}+\ldots-2^{2}+1^{2}-0^{2}=\mathrm{n}+(\mathrm{n}-1)+\ldots+2+1+0$

For example:

$4^{2}-3^{2}+2^{2}-1^{2}+0^{2}=4+3+2+1+0$.

Proof of Corollary 1 using Lemma 1. Just observe directly, pairs of numbers on both sides of equation (2): by Lemma 1 they are equal, so the whole equation (2) is valid. Formally, two cases should be considered:
Case 1: Even number of nonzero elements in the sum:

$$
\overbrace{n+(n-1)}^{n^{2}-(n-1)^{2}}+\ldots \overbrace{+2+1}^{+^{2^{2}-1^{2}}}=
$$

Case 2: Odd number of nonzero elements in the sum:

$$
\overbrace{n+(n-1)}^{n^{n^{2}-(n-1)^{2}}}+\ldots \overbrace{+3+2}^{+3^{2}-2^{2}}+1^{2}=
$$

Let us note that the statement in Corollary 1 is very well known exercise for sums of integers and can be found in many textbooks. However, to the best of our knowledge, the proof presented above is the simplest one.

\section{Obtaining a new result in Number Theory using Lemma 1}

The statement (3) can also be expressed in the following form:

$$
\mathrm{S}(\mathrm{n}, 1)=\operatorname{ASQ}(\mathrm{n}, 1),
$$

where $S(n, 1)$ is the sum of consecutive numbers from $\mathrm{n}$ down to 1 , and $\operatorname{ASQ}(\mathrm{n}, 1)$ is the alternate sum of squares of consecutive numbers from $n$ down to 1 .

Let $S(n, n-k)$ and $A S Q(n, n-k)$ be, respectively, the sum of consecutive numbers and the alternate sum of squares of those integers, from $n$ down to $\mathrm{n}-\mathrm{k}$, where $0<\mathrm{k}<\mathrm{n}$.

Here we will show that

$$
\mathrm{S}(\mathrm{n}, \mathrm{n}-\mathrm{k})=\text { ASQ }(\mathrm{n}, \mathrm{n}-\mathrm{k})
$$

when the number, $\mathrm{k}+1$, of elements in the sums is even, i.e. when $\mathrm{k}$ is odd.

In other words we will show that

$$
\sum_{i=0}^{k}(-1)^{i}(n-i)^{2}=\sum_{i=0}^{k}(n-i),
$$

where $\mathrm{k}$ is an odd number, $0<\mathrm{k}<\mathrm{n}$.

For example, for $\mathrm{k}=3, \mathrm{k}+1=4$ (number of elements in the sum), $\mathrm{n}=10$ we have:

$$
\begin{gathered}
10^{2}-(10-1)^{2}+(10-2)^{2}-(10-3)^{2}= \\
10+(10-1)+(10-2)+(10-3) \\
10^{2}-9^{2}+8^{2}-7^{2}=10+9+8+7 .
\end{gathered}
$$

Theorem 1. Let $S(n, n-k)$ and $A S Q(n, n-k)$ be as above, and let $\mathrm{k}$ be an odd number, $0<\mathrm{k}<\mathrm{n}$. Then

$$
\operatorname{ASQ}(\mathrm{n}, \mathrm{n}-\mathrm{k})=\mathrm{S}(\mathrm{n}, \mathrm{n}-\mathrm{k}) \text {. }
$$


Proof. Write the statement (3) in expanded form

$$
\begin{gathered}
\mathrm{n}^{2}-(\mathrm{n}-1)^{2}+\ldots+(\mathrm{n}-(\mathrm{k}-1))^{2}-(\mathrm{n}-\mathrm{k})^{2}= \\
\mathrm{n}+(\mathrm{n}-1)+\ldots+(\mathrm{n}-(\mathrm{k}-1))+(\mathrm{n}-\mathrm{k})
\end{gathered}
$$

Because the number of elements in the sums is even, we partition the sums on both sides of (4) into pairs:

$$
\overbrace{n+(n-1)}^{\underbrace{n^{2}-(n-1)^{2}}+\ldots+\overbrace{(n-(k-1))+(n-k)}^{(n-(k-1))^{2}-(n-k)}})^{2}=
$$

By Lemma 1, the resulting numbers for each of the corresponding pairs are equal, so the whole equation (4) is correct.

Theorem 1 and Corollary 1 imply the following:

Corollary 2. Let $n$ be a positive integer. Then, for any $\mathrm{k}$, such that $\mathrm{k}$ is odd and $0<\mathrm{k}<\mathrm{n}$ or $\mathrm{k}=\mathrm{n}-1$,

$$
\operatorname{ASQ}(\mathrm{n}, \mathrm{n}-\mathrm{k})=\mathrm{S}(\mathrm{n}, \mathrm{n}-\mathrm{k}) \text {. }
$$

\section{DISCUSSION}

Here we discuss some topics relevant to Lemma 1 and Theorem 1.

\section{Why statement in Lemma 1 has not been pointed out so far}

The Lemma 1 points out to a mathematical result that is very elementary, and it has been in front of eyes of mathematicians since difference of squares has been observed. It is interesting to think why it has been overlooked so far.

One possible answer to that question is that the knowledge of factoring the difference of two squares has overshadowed the identity (1). Because of the "difference of squares factorization rule"

$$
a^{2}-b^{2}=(a+b)(a-b)
$$

every time the pattern $a^{2}-b^{2}$ appears in front of a person trained in mathematics, almost automatically one tends to factor it. The factoring of (1) produces

$$
(n+1)^{2}-n^{2}=((n+1)+n)((n+1)-n)=2 n+1
$$

which overshadowed the identity (1).

\section{Simplicity of proving Corollary 1 and Theorem 1 using Lemma 1}

The proof using Lemma 1 in both Corollary 1 and Theorem 1 does not use the fact that both sum of numbers and alternate sum of squares are triangular numbers. The proof is direct, recognizing identity patterns of both sides of equations (2) and (3).
Mathematically speaking, the proof of Corollary 1 presented here is proof by partitioning. The problem is divided into small sub-problems which in this case are directly solvable using Lemma 1.

\section{Scientific merit}

Two new statements in Number Theory are presented. The first one is the observation stated in Lemma 1. It can be observed directly, and might be considered trivial, once it is pointed out. The second new statement, the Theorem 1, needs a previous result in order to be proven directly, and in this case the Lemma 1 is such a result.

\section{Educational merit}

The Lemma 1 shows that in both mathematics and sciences there are truths that are in front of our eyes but we do not notice them. In many cases it is because we think in terms "inside the box" and our thought process is rather structured. In case of identity (1) thinking "inside the box" means that whenever the pattern $a^{2}-b^{2}$ appears, we tend to factor it as $(a+b)(a-b)$. Thinking "outside the box" allows to see that in a special case when two numbers $a$ and $b$ are consecutive integers $(a=n+1, b=n)$, and obtained result is $(n+1)^{2}-n^{2}=2 n+1$, to look a step further, and observe the beauty of the identity $(n+1)^{2}-n^{2}=(n+1)+n$. And in addition to the observed interesting result, it is good to show that the observed identity is useful.

\section{CONCLUSION}

A new identity in Number Theory is pointed out. Example of usefulness of the observed identity is shown by obtaining a new statement in Number Theory. As educational merit, this is an example of "thinking outside the box". By thinking "outside the box", the new identity has been observed although it has been overshadowed by a factorization rule.

Acknowledgement. The author wishes to express gratitude to the referees for their remarks and suggestions toward the improvement of the quality of the paper.

\section{REFERENCES}

[1] E. Robson, Neither Sherlock Holmes nor Babylon: A reassessment of Plimpton 322. Historia Mathematica, 28: 167-206, 2001.

[2] J. Watkins, Number Theory: A Historical Approach. Princeton University Press, 2013. 
[3] G. Andrews, Number Theory, Dover Publications, 1971.

[4] U. Dudley, Elementary Number Theory, Dover Publications, 1969.
[5] C. Moreno, S. Wagstaff, Sums of Squares of Integers, Chapman and Hall, 2006.

\section{ЕДЕН ПРЕВИДЕН ИДЕНТИТЕТ ВО ТЕОРИЈАТА НА БРОЕВИ}

\section{Стево Божиновски}

Оддел за математика и компјутерски науки, Државен универзитет на Јужна Каролина, САД

и

Факултет за информатички науки и компјутерско инженерство, Универзитет „Св. Кирил и Методиј“, Скопје, Република Македонија

Укажано е на превиден идентитет во теоријата на броеви. Користејќи го новосогледаниот идентитет, добиен е нов резултат во теоријата на броеви, како и нов доказ на веќе познат резултат. Дискутирани се и образовни аспекти, при што е укажано на можно објаснување зошто овој идентитет, кој изгледа тривијален откако ќе биде укажано на него, не бил согледан досега.

Клучни зборови: теорија на броеви; превиден идентитет; сума на броеви; знак-менувачка сума на квадрати; Плимптон 322 